\title{
SIMULATION TESTS OF EXTINGUISHING PROCESS USING MIST NOZZLES WITH APPLICATION OF HYBRID FIRE MODEL
}

\author{
Jerzy GAŁAJ ${ }^{\mathrm{a}}$, Marek KONECKI ${ }^{\mathrm{a}}$, Ritoldas ŠUKYS ${ }^{\mathrm{b}}$ \\ ${ }^{a}$ Department of Fire Safety Engineering, The Main School of Fire Service, \\ Slowackiego str. 52/54, 01-692 Warsaw, Poland \\ ${ }^{b}$ Department of Labor Safety and Fire Protection, Vilnius Gediminas Technical University, \\ Sauletekio al. 11, LT-10223 Vilnius, Lithuania
}

Received 07 Oct 2015; accepted 13 Jan 2016

\begin{abstract}
The article presents a computer model of the fire extinguishing process using mist nozzles. A previously developed hybrid fire model was used for this purpose. Assumptions and relationships were given to represent a mathematical model of extinguishing process, which comprises a unique approach to the determination of sprinkling area in an elementary cell of field fire model. A description of simulation tests of the model was given for several different input data, differing by mean diameters of droplets. This enabled a study of their effects on such output parameters as received heat flux, temperature and rate of its growth. For one selected computational cell located on the axis of the nozzle at floor level having the coordinates $[10,10,1]$, the obtained results were presented in the form of heat flux and temperature. To simplify the analysis, characteristic parameters of particular curves were listed in the table. Conclusions formulated on the basis of results obtained during tests were specified at the end of work. They confirmed the expected regularity assuming that the extinguishing process was more effective in the case of droplets of a smaller diameter and greater sprinkling intensity. This allows assessing the degree, to which these stream parameters affect the extinguishing effectiveness.
\end{abstract}

Keywords: extinguishing process, mist nozzle, fire suppression, computer modelling, field fire model, hybrid fire model.

\section{Notation}

$\tau$

$\tau_{0}$

$g$

$D$

$h_{v}$

$\rho_{k}$

$T_{w}$

$M_{w}$

$M_{p}$

$B$

$F_{k}[i, j, k, l]$

$F_{g}[i, j, k, l]$

$F_{g p}[i, j, k, l]$

current time, $\mathrm{s}$

unit time, $s$

in the air, $\mathrm{m}^{2} / \mathrm{s}$ $\mathrm{kg} / \mathrm{m}^{3}$

during $1 \mathrm{~s}, \mathrm{~m}^{2}$

the drops fly, $\mathrm{m}^{2}$ evaporation in the cell $[\mathrm{i}, \mathrm{j}, \mathrm{k}, \mathrm{l}], \mathrm{m}^{2}$

acceleration due to gravity, $\mathrm{m} / \mathrm{s}^{2}$

coefficient of diffusion of water vapour

water vaporization heat, $\mathrm{J} / \mathrm{kg}$

average density of a water droplet,

temperature of boiling water, $\mathrm{K}$

molar mass of water, $\mathrm{kg} / \mathrm{kmol}$

molar mass of air, $\mathrm{kg} / \mathrm{kmol}$

universal gas constant, $\mathrm{J} /(\mathrm{kmol} \cdot \mathrm{K})$

total area of all water drops

passing through the cell $[i, j, k, l]$

average size of the horizontal surface

of the cell $[i, j, k, l]$, through which $\alpha[i, j, k, l]$

$N u[i, j, k, l]$

$\operatorname{Re}[i, j, k, l]$

forced convection in the cell $[i, j$,
Reynolds number characterizing

the turbulent flow of droplets in the cell

$[i, j, k, l]$

$w_{d}[i, j, k, l] \quad$ average speed of drops in the

cell $[i, j, k, l], \mathrm{m} / \mathrm{s}$

$w[i, j, k, l] \quad$ average speed of gas in the cell

$[i, j, k, l], \mathrm{m} / \mathrm{s}$

$v[i, j, k, l] \quad$ mean kinematic viscosity in the cell

$[i, j, k, l], \mathrm{m}^{2} / \mathrm{s}$

$T[i, j, k, l] \quad$ average gas temperature in the cell

$[i, j, k, l], \mathrm{K}$

$\lambda[i, j, k, l] \quad$ average value of gas thermal conductivity in the cell $[i, j, k, l], \mathrm{W} /(\mathrm{mK})$

$\rho[i, j, k, l] \quad$ average gas density in the cell $[i, j, k, l]$, $\mathrm{kg} / \mathrm{m}^{3}$

$\operatorname{Pr}[i, j, k, l] \quad$ average value of the Prandtl number in the cell $[i, j, k, l]$

Corresponding author: Ritoldas Šukys

E-mail: ritoldas.sukys@vgtu.lt 


\begin{tabular}{|c|c|}
\hline$S h[i, j, k, l]$ & $\begin{array}{l}\text { average value of the Sherwood number } \\
\text { in the cell } i j i\end{array}$ \\
\hline$S c[i, j, k, l]$ & $\begin{array}{l}\text { average value of the Schmidt number } \\
\text { in the cell }[i, j, k, l]\end{array}$ \\
\hline$d m_{k} / d t[i, j, l]$ & $\begin{array}{l}\text { average value of mass flux of an evapo- } \\
\text { rated droplet in the cell }[i, j, k, l], \mathrm{kg} / \mathrm{s}\end{array}$ \\
\hline$X_{k}$ & $\begin{array}{l}\text { volume fraction of vapour in a water } \\
\text { droplet }\end{array}$ \\
\hline$Y_{k}$ & $\begin{array}{l}\text { mass fraction of vapour in a water } \\
\text { droplet }\end{array}$ \\
\hline$N_{k p}[i, j, k, l]$ & $\begin{array}{l}\text { average number of drops evaporated in } \\
\text { the cell }[i, j, k, l]\end{array}$ \\
\hline$\delta_{0}[i, m]$ & $\begin{array}{l}\text { average diameter of drops produced by } \\
\text { the } \mathrm{m}^{\text {th }} \text { mist nozzle in the } \mathrm{i}^{\text {th }} \text { compart- } \\
\text { ment, } \mathrm{mm}\end{array}$ \\
\hline$I[i, m]$ & $\begin{array}{l}\text { average value of sprinkling intensity } \\
\text { by the } m^{\text {th }} \text { mist nozzle }\end{array}$ \\
\hline$\alpha_{0}[i, m]$ & $\begin{array}{l}\text { in the } i^{\text {th }} \text { compartment, } \mathrm{mm} / \mathrm{min} \\
\text { spray angle of the } m^{\text {th }} \text { mist nozzle } \\
\text { in the } i^{\text {th }} \text { compartment, rad }\end{array}$ \\
\hline $\begin{array}{l}\rho_{l} \\
\rho[i, j, k, l]\end{array}$ & $\begin{array}{l}\text { water density, } \mathrm{kg} / \mathrm{m}^{3} \\
\text { gas density in the cell }[i, j, k, l], \mathrm{kg} / \mathrm{m}^{3}\end{array}$ \\
\hline
\end{tabular}

\section{Introduction}

Water is characterized by high specific heat $(4.19 \mathrm{~kJ} /$ $(\mathrm{kgK}))$, high vaporization heat $(2260 \mathrm{~kJ} / \mathrm{kg})$ and low boiling temperature (ca. $100^{\circ} \mathrm{C}$ ). When applied directly to the source of fire, it can absorb heat from gases, flames and fuel, as well as from the surface adjacent to the fire. The cooling of these areas changes depending on the diameter of water drops. The reduction in the size of the drops gives a larger cooling surface. Heat transfer is increased so that fog systems can pick up energy from the burning zone faster and more efficiently. The surface of the water vapour increases exponentially with a decrease in the diameter of the drops (Mawhinney, Solomon 2000; Mawhinney 2012; Orzechowski, Prywer 2008). Floating in the air, small water droplets form a barrier that limits the speed of pyrolysis (evaporation in the case of liquids) close to the combustion zone. Isolation of the thermal radiation increases with the degree of water mist spray. Water sprayed in smaller droplets not only receives heat better but also greatly increases the area protected by the same quantity of water. The effect of fire suppression using water vapour is obtained mostly because of the dilution air (oxygen) in the combustion zone; having in mind that one litre of evaporated water produces more than 1700 litres of steam. Water vaporizes very quickly, displacing the air in the vicinity of a drop. The application of water mist containing droplets of a diameter up to $1 \mathrm{~mm}$ as the extinguishing agent offers numerous advantages. It greatly reduces the risk of consequent losses in the administration of water and enables its efficient use. The use of large amounts of water in extinguishing a fire may result in significant losses due to the destruction of dampened materials, structural elements of a building, furniture, etc. Fog systems, which enhance the fire-extinguishing effect of water, can prevent such damages. During the first stage, lager diam- eter drops should be used to fully extinguish a fire. However, this decision should be weighed against the risk of water condensation and post-fire losses. In many cases, a much better option is to use water mist for cooling the fire gases and fire suppression to delay flashover phenomena. The second option, however, does not guarantee that the fire would be extinguished; nevertheless, it is focused on limiting its further development. Under appropriate conditions, fire suppression may also lead to the complete extinguishing of the fire.

The analysis of the extinguishing properties of water mist provides that its efficiency increases with the increasing degree of dispersion. This means that a fire can be extinguished by small amounts of water thanks to an effective use of its cooling properties. Numerous arguments can justify the use of the smallest drops. A reduction in the diameter of droplets improves their cooling and penetrating properties as well as the time of droplet suspension in the air. In addition, small droplets can get into hard-to-reach spaces, circulating around obstacles and accessing the fire. It is also easier to disrupt their flight path, e.g. due to turbulence.

According to Paul Grimwood, the ultimate mist fire spray contains droplets of an average diameter of $0.3 \mathrm{~mm}$. He specified the optimal scope of applicability from $0.2 \mathrm{~mm}$ to $0.4 \mathrm{~mm}$ (Grimwood 2002; Grimwood, Desmet 2003; Zbrożek, Prasuła 2009). Based on tests, Grimwood (2002) concluded that small droplets were subject to interaction with the fire column, which would result in a need to apply more water to achieve an effective cooling speed. On the other hand, drops above the specified range may not be suspended in the air. The presented opinion is suitable for a local action, especially when fighting a group A fire (Davis 2000). In order to achieve the best cooling parameters, especially when treated with volume, one should strive to achieve a high degree of dispersion. This was confirmed by diverse theoretical and experimental studies. The effectiveness of water mist extinguishing systems with a drop diameter of up to $0.01 \mathrm{~mm}$, the smallest that is technically feasible, was confirmed by NanoMist Systems, LLC. The relevant information may be found on the website of the National Fire Protection Association (2015). Telesto Sp. z o. o., a company operating on the Polish market, makes an effective use of a fog containing droplets of the diameter of $0.025 \mathrm{~mm}$ (Telesto Sp. z o. o. 2015). It exceeds by far the lower limit considered by Grimwood (2002) as optimum.

Mist nozzles used in fire-fighting systems, similarly as in other systems, can be automatically started using detection by a liquid-filled ampoule that extends with increasing temperature, and non-automatic nozzles (open), run by an independent detection system. Depending on the used technology, water mist can be produced under operating pressure ranging from $0.5 \mathrm{MPa}$ to more than $20 \mathrm{MPa}$ (Hanuska, Black 1993; Grant et al. 2000; Orzechowski, Prywer 2008; Myree 2008; Whiteley 2009; NFPA 2000; Palau 2005). Both the fire and the extin- 
guishing process are very complex physical phenomena, which are difficult to model precisely using available computer hardware and software. Nevertheless, a number of programs were devised for modelling fire development. Several programs also provide fire extinguishing modules using mist nozzles or sprinklers. The two most popular models of fire are the CFAST two-zone fire model and FDS field model (Jones et al. 2009; McGrattan et al. 2007; Novozhilov 2001). In the first instance, a relatively simple model was applied to calculate heat changes during the extinguishing process by means of a sprinkler. The correlation of fire suppression by the sprinkler system has been developed by modifying the heat release rate of fire in the following form (Jones et al. 2009):

$$
Q_{f}(t)=Q\left(t_{a c t}\right) \cdot e^{-\frac{t-t_{a c t}}{3 \cdot Q_{s p r a y}^{-1.8}}}
$$

where: $Q_{f}(t)$ is the heat release ratio at time t [W]; $Q\left(t_{a c t}\right)$ - heat release ratio at time $t_{a c t}[\mathrm{~W}] ; t_{a c t}$ - sprinkler response time [s], and $Q_{\text {spray }}$ - sprinkling intensity of the sprinkler $[\mathrm{mm} / \mathrm{min}]$.

Unfortunately, the proposed model has many limitations. One of them is the assumption that the amount of water applied to the fire is sufficient to cause a decline in the rate of heat release and that the sprinkling intensity is constant. In addition, it did not take into account the effect of the second sprinkler. Detection of other sprinklers was taken into consideration, but it did not affect the extinguishing process.

The FDS (Fire Dynamics Simulator) field fire model is one of the most popular programs in CFD (Computational Fluid Dynamics), which are established according to complicated methods and algorithms, designed to analyse and solve problems related to the flow of viscous fluids. This technique is based on numerical solution of Navier-Stokes equations, suitable for low flow velocities (values of the Mach number are low). The emphasis is on the smoke and heat transport. FDS is a free program developed by the NIST (National Institute of Standards and Technology). Obtained simulation results can be presented graphically using the Smokeview visualization program. The program also has a module that simulates the evacuation. As regards the extinguishing process, it enables a simulation of sprinkler activation, and calculations of drop trajectory, as well as tracking the drops falling down onto the surface of the fire. Besides, the drop transportation on surfaces as well as absorption and dissipation of thermal radiation by the drops are included.

The weakening of the thermal radiation is particularly important in the case of mist systems. For each drop, the power consumed by a combination of absorption and scattering is calculated based on the formula (Cong, Liao 2005; Novozhilov 2001):

$$
\dot{q}_{r}=\frac{m_{d}}{\rho_{d}(x)} \cdot \kappa_{d}(x) \cdot\left[U(x)-4 \cdot \pi \cdot I_{b, d}(x)\right],
$$

where: $m_{d}$ is the weight of the drop $[\mathrm{kg}] ; \rho_{d}(x)-$ density of the drop in the cell $\left[\mathrm{kg} / \mathrm{m}^{3}\right] ; \kappa_{d}(x)$ - absorption coefficient of the drop by solids $[1 / \mathrm{m}] ; U(x)-$ total intensity of thermal radiation $\left[\mathrm{kW} / \mathrm{m}^{2}\right]$; and $I_{b, d}(x)$ - total absorption of thermal radiation by drops $\left[\mathrm{kW} / \mathrm{m}^{2}\right]$.

Heating and evaporation of water droplets are also modelled. The weight and energy transfer between gas and liquid is calculated on the basis of the following four equations (Cong, Liao 2005):

$$
\begin{gathered}
\frac{d m_{l}}{d t}=-2 \pi \cdot r_{d} \cdot S h \cdot \rho \cdot D_{t g} \cdot\left(Y_{d}-Y_{g}\right) ; \\
S h=2+0.6 \mathrm{Re}^{\frac{1}{2}} \cdot S c^{\frac{1}{3}} ;
\end{gathered}
$$

$$
\begin{aligned}
m_{l} \cdot c_{l} \cdot \frac{d T_{l}}{d t}= & 2 \pi \cdot r_{d} \cdot N u \cdot k \cdot\left(T_{g}-T_{l}\right)+ \\
& 2 \pi \cdot r_{d} \cdot h_{s} \cdot\left(T_{g}-T_{l}\right)+\dot{q}_{r}+\frac{d m_{l}}{d t} \cdot h_{v},
\end{aligned}
$$

and

$$
N u=2+0.6 \operatorname{Re}^{\frac{1}{2}} \cdot \operatorname{Pr}^{\frac{1}{3}},
$$

where: $m_{l}$ is the weight of drops $[\mathrm{kg}] ; D_{t g}-$ diffusion coefficient of water vapour into the air; $Y_{d}$ - mass fraction of water vapour in a liquid phase; $Y_{g}$ - mass fraction of gas in water vapour phase; $S h$ - Sherwood number; $r_{d}-$ drop diameter $[\mathrm{m}] ; \rho$ - water density $\left[\mathrm{kg} / \mathrm{m}^{3}\right] ; c_{l}$ - specific heat of water $[\mathrm{J} /(\mathrm{kg} \mathrm{K})] ; \mathrm{Nu}$ - nusselt number; $\mathrm{Pr}-$ Prandtl number ( 0.7 is assumed for all cases); $k$ - gas thermal conductivity $[\mathrm{W} /(\mathrm{mK})] ; T_{g}-$ air temperature $[\mathrm{K}]$; $T_{l}$ - water temperature $[\mathrm{K}] ; T_{s}$ - temperature of a solid body $[\mathrm{K}] ; h_{s}$ - heat transfer coefficients between the fixed surface and liquid $\left[\mathrm{W} / \mathrm{m}^{2} \mathrm{~K}\right]$, and $q_{r}$ - heating rate of drops by radiation $[\mathrm{K} / \mathrm{min}]$.

The model is rather complex; however, when water drops fall on the surface on fire, easy heat transfer correlations become much more difficult as water not only cools down the surface and ambient gas but also changes the rate of fuel pyrolysis. The surface of the fuel is rarely flat and usually has a complex structure, which greatly complicates the problem. Yet since the first public release in the year 2000, the program has been continually developed using analyses of dozens of fires. In the future, this will allow a more accurate approximation of fire suppression (McGrattan et al. 2007).

The main objective of this study was to carry out simulation tests, on the basis of which it would be possible to determine the impact of the selected parameters, such as sprinkling intensity, and the average diameter of the water drops on the effectiveness of fire extinguishing using mist nozzles. The simulation tests used a computer model of extinguishing process developed at the Main School of Fire Service, which works together with a hybrid model of the fire described by Gałaj (2009, 2010a, 2010b). This model will be validated using results 
obtained during investigations described in the following papers (Konecki, Półka 2009; Gałaj, Konecki 2010; Gałaj et al. 2013; Półka et al. 2013).

The first chapter of this work presents assumptions and discusses the extinguishing process model. The following section gives a description of the tests as well as simulation results and their analysis. The last chapter provides a summary and conclusions formulated on the basis of computer simulation results.

\section{Model of the extinguishing process}

As a result of works carried out in the Firefighting Technique Department of the Main School of Fire Service, a mathematical model of the fire extinguishing process was developed. The model was based on relationships connected with the heat flux calculations, taking into account the heat exchange by convection as well as the heat received from the combustion zone as a result of the water droplet evaporation. The original contribution of the authors is the formulas used to determine the surface of heat received by any regular cell, resulting from a division of the compartment in a hybrid model of fire. A computer program was developed incorporating the abovementioned mathematical model, which then was coupled with the earlier hybrid fire model. One of the coupling elements is a database that contains both the data associated with an extinguishing process and fire growth.

In a physical model of the extinguishing process, the following assumptions were adopted:

1) the average diameter of all drops and the sprinkling intensity are the same for the $m^{\text {th }}$ mist nozzle in the $i^{\text {th }}$ room and are equal to $\delta_{0}[i, m]$ and $I[i, m]$, respectively;

2 ) the average speed of all drops in the cell is the same and equals to $w_{d}[i, j, k, l]$. It is calculated by the formula for turbulent descent speed given in (Orzechowski, Prywer 2008);

3 ) a constant diffusion coefficient of water relative to the ambient air $D$ was assumed;

4) the average outlet velocity of the drops is constant and equals to $w_{0}$;

5) a uniform and symmetric water spray was assumed;

6) drops decay phenomena and the impact of the turbulence on their movement were disregarded;

7) only this part of the heat flux was taken into account, which is exchanged by convection and as a result of droplet evaporation. The phenomenon of oxygen displacement and radiation weakening was disregarded;

8) according to the assumption, the total evaporation of water drops takes place only in these cells, where the average temperature exceeds the established fixed boiling point;

9) a constant heat of water vaporization $h_{v}$ and boiling temperature $T_{b}$ were assumed;

10) an average value of the surface $F_{g}$ was assumed, through which the droplets permeate as through a horizontal surface situated at mid-level of cell height;
11) temperature $T_{l}$ of all drops is the same;

12) for the determination of heat absorption indices between the droplet and the surrounding air in the convection and evaporation processes, standard correlation values were adopted, which are commonly cited global literature;

13) the average surface $F_{g}[i, j, k, l]$, through which drops penetrate, was determined in a similar way by replacing arches with chords (Fig. 2). Depending on the position of a cell relative to the sprinkling area, a trapezoid or triangle is obtained.

Below is a mathematical model of the extinguishing process in the form of a set of equations. It is valid for all calculated cells, which are covered by the spray jet generated by mist nozzles. The vertical section of the spray on the background of the computing grid is shown in Figure 1.

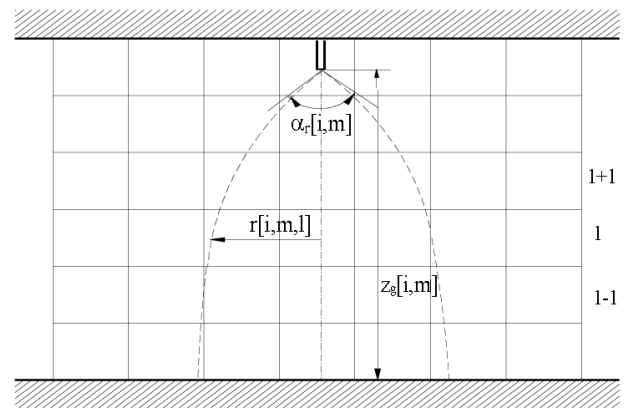

Fig. 1. Vertical section of the spray set against a background of the computing grid

The heat flux received by water drops during convection and evaporation for every cell $[j, k, l]$ located in the $i^{\text {th }}$ room can be calculated from the following relationships ( $m$ is the number of mist nozzles, and $i$ is the number of rooms):

$$
\begin{aligned}
& \dot{Q}_{g}[i, m, j, k, l]=K_{k} \cdot \alpha[i, m, j, k, l] \cdot F_{k}[i, m, j, k, l] \cdot \\
& \left(T[i, j, k, l]-T_{l}\right)+-K_{p} \cdot N_{k p}[i, m, j, k, l] . \\
& \frac{d m_{d}}{d t}[i, m, j, k, l] \cdot h_{v},[\mathrm{~W}]
\end{aligned}
$$

and

$$
\dot{Q}_{g t}[i, j, k, l]=\sum_{m=1}^{m \max [i]} Q_{g}[m],[\mathrm{W}],
$$

where:

$$
\begin{aligned}
& F_{k}[i, m, j, k, l]=\frac{I[i, m] \cdot F_{g}[i, m, j, k, l] \cdot \tau_{0} \cdot 10^{5}}{\delta_{0}[i, m]},\left[\mathrm{m}^{2}\right] ;(9) \\
& v[i, j, k, l]=7.18 \cdot 10^{-10} \cdot\left(\frac{T[i, j, k, l]-T_{l}}{2}\right)^{7 / 4},\left[\mathrm{~m}^{2} / \mathrm{s}\right] ;(10) \\
& \lambda[i, j, k, l]=6.5 \cdot 10^{-8} \cdot\left(\frac{T[i, j, k, l]}{2}\right)^{4 / 5},[\mathrm{~W} /(\mathrm{m} \cdot \mathrm{K})] ;(11)
\end{aligned}
$$


$\rho[i, j, k, l]=\frac{p[i, j, k, l]}{R[i, j, k, l] \cdot T[i, j, k, l]},\left[\mathrm{kg} / \mathrm{m}^{3}\right]$

$w_{d}[i, m, j, k, l]=$

$1.74 \cdot \sqrt{\frac{g \cdot\left(\rho_{l}-\rho[i, j, k, l]\right) \cdot \delta_{0}[i, m] \cdot 10^{-3}}{\rho[i, j, k, l]}},[\mathrm{m} / \mathrm{s}] ;$

$\operatorname{Re}[i, m, j, k, l]=$

$\frac{\left(w_{k}[i, m, j, k, l]-w[i, j, k, l]\right) \cdot \delta_{0}[i, m] \cdot 10^{-3}}{v[i, j, k, l]} ;$

$\operatorname{Pr}[i, j, k, l]=\frac{c_{p} \cdot v[i, j, k, l] \cdot \rho[i, j, k, l]}{\lambda[i, j, k, l]} ;$

$N u[i, m, j, k, l]=2+0.6 \cdot \operatorname{Re}^{1 / 2}[i, m, j, k, l] \cdot \operatorname{Pr}[i, j, k, l]^{1 / 3} ;$

$\alpha[i, m, j, k, l]=\frac{N u[i, m, j, k, l] \cdot \lambda[i, j, k, l]}{\delta_{0}[i, m] \cdot 10^{-3}},\left[\mathrm{~W} /\left(\mathrm{m}^{2} \mathrm{~K}\right)\right]$

$$
S c[i, j, k, l]=\frac{v[i, j, k, l]}{D}
$$

$\left.S h[i, m, j, k, l]=2+0.6 \cdot \operatorname{Re}^{1 / 2}[i, m, j, k, l] \cdot S c[i, j, k, l]\right]^{1 / 3}$

$$
\begin{gathered}
X_{d}=\exp \left[\frac{h_{p} \cdot M_{w}}{B} \cdot\left(\frac{1}{T_{b}}-\frac{1}{T_{l}}\right)\right] ; \\
Y_{d}=\frac{X_{d}}{X_{d} \cdot\left(1-M_{a} / M_{l}\right)+M_{a} / M_{l}} ;
\end{gathered}
$$

$\frac{d m_{d}}{d t}[i, m, j, k, l]=-\pi \cdot \delta_{0}[i, m] \cdot 10^{-3} \cdot S h[i, m, j, k, l] *$

$* \rho[i, j, k, l] \cdot D \cdot Y_{d},[\mathrm{~kg} / \mathrm{s}]$;

$N_{k p}[i, m, j, k, l]=\frac{I[i, m] \cdot F_{g p}[i, m, j, k, l] \cdot \tau_{0} \cdot 10^{5}}{\pi \cdot \delta_{0}^{3}[i, m]}$.

A unique solution in the extinguishing model is proposed, i.e. a new algorithm for determining of sprinkling and evaporation area in individual computing cells.

Formulas used for calculation of sprinkling $F_{g}$ and evaporation area $F_{g p}$ in different most common variants are given below:

1. The algorithm for determining the sprinkling area $F_{g}[i, j, k, l]$ in the cell $[i, j, k, l]$ :

a) $F_{g}[i, m, j, k, l]=0$.
All the corners of the cell $\left(x_{1}, y_{1}\right),\left(x_{1}, y_{2}\right),\left(x_{2}, \mathrm{y}, 1\right)$ and $\left(x_{2}, y_{2}\right)$ do not belong to the sprinkling area with a radius of $r[i, m, l]$. Then, all four of the following inequalities should be satisfied:

$$
\begin{aligned}
& \sqrt{\left(x_{1}-x_{g}[i, m]\right)^{2}+\left(y_{2}-y_{g}[i, m]\right)^{2}} \geq r[i, m, l], \\
& \sqrt{\left(x_{1}-x_{g}[i, m]\right)^{2}+\left(y_{1}-y_{g}[i, m]\right)^{2}} \geq r[i, m, l], \\
& \sqrt{\left(x_{2}-x_{g}[i, m]\right)^{2}+\left(y_{2}-y_{g}[i, m]\right)^{2}} \geq r[i, m, l] \text { and } \\
& \sqrt{\left(x_{2}-x_{g}[i, m]\right)^{2}+\left(y_{1}-y_{g}[i, m]\right)^{2}} \geq r[i, m, l] . \\
& \text { b) } F_{g}[i, m, j, k, l]=\Delta x_{k} \cdot \Delta y_{k} .
\end{aligned}
$$

If all the corners of the cell $\left(x_{1}, y_{1}\right),\left(x_{1}, y_{2}\right),\left(x_{2}, y_{1}\right)$ and $\left(x_{2}, y_{2}\right)$ belong to the sprinkling area with a radius of $r$ $[i, m, l]$, then all four of the following inequalities should be satisfied:

$$
\begin{aligned}
& \sqrt{\left(x_{1}-x_{g}[i, m]\right)^{2}+\left(y_{2}-y_{g}[i, m]\right)^{2}}<r[i, m, l], \\
& \sqrt{\left(x_{1}-x_{g}[i, m]\right)^{2}+\left(y_{1}-y_{g}[i, m]\right)^{2}}<r[i, m, l], \\
& \sqrt{\left(x_{2}-x_{g}[i, m]\right)^{2}+\left(y_{2}-y_{g}[i, m]\right)^{2}}<r[i, m, l] \text { and } \\
& \sqrt{\left(x_{2}-x_{g}[i, m]\right)^{2}+\left(y_{1}-y_{g}[i, m]\right)^{2}}<r[i, m, l] . \\
& F_{g}[i, m, j, k, l]=\Delta x_{k} \cdot \Delta y_{k}-0.5 \cdot\left(x_{2}-x_{r 2}\right) \cdot\left(y_{2}-y_{r 2}\right) .
\end{aligned}
$$

If for $x_{1} \geq x_{g}[i, m] \wedge y_{1} \geq y_{g}[i, m]$ (first quarter) the following inequalities are satisfied (three points in a sprinkling area):

$$
\begin{aligned}
& \sqrt{\left(x_{1}-x_{g}[i, m]\right)^{2}+\left(y_{1}-y_{g}[i, m]\right)^{2}}<r[i, m, l], \\
& \sqrt{\left(x_{1}-x_{g}[i, m]\right)^{2}+\left(y_{2}-y_{g}[i, m]\right)^{2}}<r[i, m, l], \\
& \sqrt{\left(x_{2}-x_{g}[i, m]\right)^{2}+\left(y_{1}-y_{g}[i, m]\right)^{2}}<r[i, m, l] \text { and } \\
& \sqrt{\left(x_{2}-x_{g}[i, m]\right)^{2}+\left(y_{2}-y_{g}[i, m]\right)^{2}}>r[i, m, l] .
\end{aligned}
$$

Similar geometric formulas and corresponding inequalities were determined for all possible cases of mutual position of the cell and sprinkling area.

Where:

$$
K[i, j, k, l]=\frac{18 \cdot \rho[i, j, k, l] \cdot v[i, j, k, l]}{\rho_{l} \cdot \delta_{0}^{2}[i, m] \cdot 10^{-6}} ;
$$


and

$$
\begin{aligned}
& z_{g}[i, m]-(l-0.5) \cdot \Delta z_{k}=\frac{w_{0} \cdot \sin \left(\frac{\pi}{2}-\frac{\alpha_{0}}{2}\right)-\frac{g}{K[i, j, k, l]}}{K[i, j, k, l]} . \\
& \left(1-e^{-K[i, j, k, l] \cdot \tau[i, j, k, l]}\right)+\frac{g \cdot \tau[i, j, k, l]}{K[i, j, k, l]},
\end{aligned}
$$

hence

$$
\tau[i, j, k, l],
$$

$$
\begin{aligned}
& \frac{\operatorname{tg} \frac{\alpha_{r}[i, m, l]}{2}=}{w_{0} \cdot \cos \left(\frac{\pi}{2}-\frac{\alpha_{0}}{2}\right) \cdot e^{-K[i, j, k, l] \cdot \tau(i, m, l)}} \\
& {\left[w_{0} \cdot \sin \left(\frac{\pi}{2}-\frac{\alpha_{0}}{2}\right)-\frac{g}{K[i, j, k, l]}\right] \cdot e^{-K[i, j, k, l] \cdot \tau(i, m, l)}+\frac{g}{K[i, j, k, l]}}
\end{aligned}
$$

$$
\begin{gathered}
x_{1}=(j-1) \cdot \Delta x_{k} ; \\
x_{2}=j \cdot \Delta x_{k} ; \\
y_{1}=(k-1) \cdot \Delta y_{k} ; \\
y_{2}=k \cdot \Delta y_{k} ;
\end{gathered}
$$$$
r[i, m, l]=r[i, m, l+1]+\Delta z_{k} \cdot \operatorname{tg} \frac{\alpha_{r}[i, m, l]}{2}
$$

$x_{r 1}=x_{g}[i, m]+\sqrt{r^{2}[i, m, l]-\left(y_{1}-y_{g}[i, m]\right)^{2}}$

$x_{r 2}=x_{g}[i, m]+\sqrt{r^{2}[i, m, l]-\left(y_{2}-y_{g}[i, m]\right)^{2}}$

$y_{r 1}=y_{g}[i, m]+\sqrt{r^{2}[i, m, l]-\left(x_{1}-x_{g}[i, m]\right)^{2}}$

and

$y_{r 2}=y_{g}[i, m]+\sqrt{r^{2}[i, m, l]-\left(x_{2}-x_{g}[i, m]\right)^{2}}$.

2. The formula designed to determine the evaporation surface $F_{g p}[i, m, j, k, l]$ in the cell $[i, j, k, l]$ is as follows:

$F_{g p}[i, m, j, k, l]=\left\{\begin{array}{l}0 \quad \text { if } T[i, j, k, l]<T_{w} \\ F_{g}[i, m, j, k, l] \quad \text { if } T[i, j, k, l] \geq T_{w}\end{array}\right.$.

Examples of the determination of a sprinkling area for selected cells are shown in Figure 2.

\section{Description of the computer program and simulation tests}

On the basis of a mathematical model discussed in Section 1, a computer program was developed, the main task

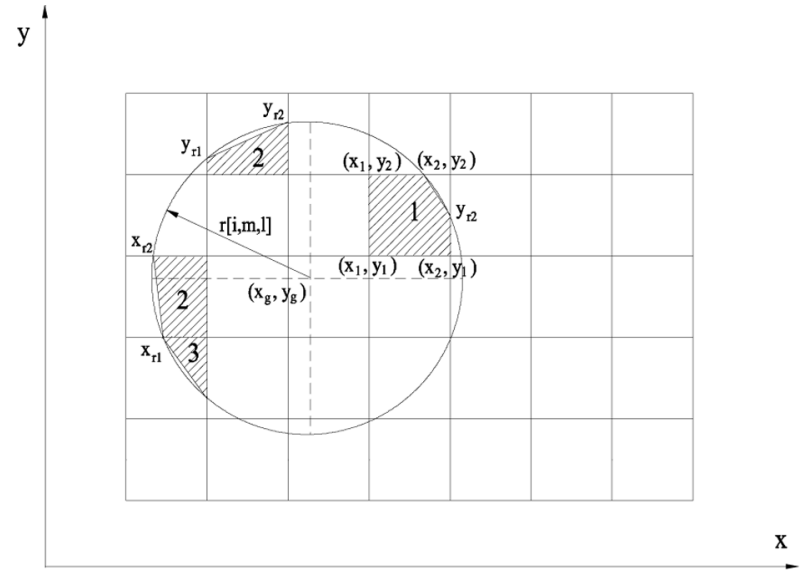

Fig. 2. Examples of the determination of the sprinkling area for selected cells ( 1 - three points in the sprinkling area, 2 - two points in the sprinkling area, 3 - one point in the sprinkling area)

of which is the determination of the heat flux received from the combustion zone by water spray. It constitutes a part of a larger program that simulates the development of a fire, which is discussed in the works of Gałaj (2009, 2010a, 2010b). A proper operation of the program requires the user to enter input data. Table 1 presents the list of such data along with an indication of the range of acceptable values.

Table 1. Input data entered by the user and their numeric ranges

\begin{tabular}{c|c|c|c|c}
\hline No. & Description & Unit & $\begin{array}{c}\text { Minimum } \\
\text { value }\end{array}$ & $\begin{array}{c}\text { Maximum } \\
\text { value }\end{array}$ \\
\hline 1. & $I[i, m]$ & $\mathrm{mm} / \mathrm{min}$ & 4 & 30 \\
\hline 2. & $\delta_{0}[i . m]$ & $\mathrm{mm}$ & 0.05 & 3 \\
\hline 3. & $K_{k}[i]$ & - & 0.1 & 1 \\
\hline 4. & $K_{p}[i]$ & - & 0.1 & 1 \\
\hline 5. & $T_{k}[i]$ & $\mathrm{K}$ & 283 & 303 \\
\hline 6. & $\alpha_{0}[i, m]$ & $\mathrm{rad}$ & $\pi / 6$ & $3 / 4 \pi$ \\
\hline 7. & $x_{g}[i, m]$ & $\mathrm{m}$ & 0.05 & $\mathrm{~L}[i]-0.05$ \\
\hline 8. & $y_{g}[i, m]$ & $\mathrm{m}$ & 0.05 & $\mathrm{~L}[i]-0.05$ \\
\hline 9. & $z_{g}[i, m]$ & $\mathrm{m}$ & $\mathrm{H}[i]-0.5$ & $\mathrm{H}[i]-0.05$ \\
\hline 10. & $\tau_{g}[i, m]$ & $\mathrm{s}$ & 0 & 3000 \\
\hline 11. & $T_{g}[i, m]$ & $\mathrm{K}$ & 323 & 373 \\
\hline 12. & $L[i]$ & $\mathrm{m}$ & 1 & 10 \\
\hline 13. & $W[i]$ & $\mathrm{m}$ & 1 & 10 \\
\hline 14. & $H[i]$ & $\mathrm{m}$ & 1 & 10 \\
\hline & & & &
\end{tabular}

The fire model used in the work was significantly simplified. The adopted combustion zone comprised a room of the following dimensions: the length of $4 \mathrm{~m}$, the width of $4 \mathrm{~m}$ and the height of $2.3 \mathrm{~m}$. There was one mist nozzle in the room mounted at the point of coordinates $\left(x_{g}, y_{g}, z_{g}\right)$. The following constant values of input data were assumed in the model:

a) drop temperature, $T_{k}=283 \mathrm{~K}\left(t_{k}=10{ }^{\circ} \mathrm{C}\right)$; 
b) spray angle, $\alpha=80^{\circ}$;

c) dimensions of cells, $x_{k}=y_{k}=z_{k}=0.20 \mathrm{~m}$;

d) density of water drops, $\rho_{k}=1000 \mathrm{~kg} / \mathrm{m}^{3}$;

e) constant pressure in the room (its fluctuations do not exceed $100 \mathrm{~Pa}$ ), $p=101300 \mathrm{~Pa}$;

f) diffusion coefficient, $D=225 * 10^{-3} \mathrm{~m}^{2} / \mathrm{s}$;

g) coordinate $O x$ of the position of the nozzle outlet, $x_{g}=1.9 \mathrm{~m}$;

h) coordinate $O y$ of the position of the nozzle outlet $y_{g}=1.9 \mathrm{~m}$;

i) coordinate $\mathrm{Oz}$ of the position of the nozzle outlet, $z_{g}=2.2 \mathrm{~m}$

j) initial temperature of air in the cell, $T_{0}[i, j, k, l]=$ $293 \mathrm{~K}\left(t_{0}=20^{\circ} \mathrm{C}\right)$.

The simulation comprised the process of fire extinguishing using a mist spray. The central cell $[10,10$, 1] was tested, which was situated at the floor level and through which passed the axis of the nozzle. It was assumed that the fire was initiated when the temperature exceeded the value of $60{ }^{\circ} \mathrm{C}$ in the cell containing the nozzle.

The assumed heat release rate for a single cell can be determined according to the following schema:

$$
\dot{Q}_{f}[i, j, k, l]=\left\{\begin{array}{lr}
0.02 \cdot \tau^{2} & \text { for } 0 \leq \tau \leq 122 \\
298 & \text { for } 122<\tau \leq 142 \\
298 \cdot[1-1.75 \cdot(\tau-142) / 40] & \text { for } \tau>142
\end{array} .\right.
$$

To investigate the influence of differing sprinkling intensities and average drop diameters on the extinguishing effectiveness, six simulation tests for the following values of the sprinkling intensity and average drop diameters were conducted:

1. Two different sprinkling intensities:

a) $I=5 \mathrm{~mm} / \mathrm{min}=0.83 * 10^{-4} \mathrm{~m} / \mathrm{s}$ and

b) $I=10 \mathrm{~mm} / \mathrm{min}=1.66 * 10^{-4} \mathrm{~m} / \mathrm{s}$.

2. Three different diameters:
a) $\delta_{0}=0.3 \mathrm{~mm}$,
b) $\delta_{0}=0.6 \mathrm{~mm}$ and
c) $\delta_{0}=0.9 \mathrm{~mm}$.

During computer simulations output files are created including the following parameters:

a) $\dot{Q}_{g}[1,10,10,1]=f(\tau)-$ heat flux received by the spray in the cell $[10,10,1], \mathrm{W}$;

b) $\dot{Q}_{f}[1,10,10,1]=f(\tau)-$ heat release rate in the cell $[10,10,1], \mathrm{W}$;

c) $t[1,10,10,1]=f(\tau) \quad$ - average temperature in the cell $[10,10,1],{ }^{\circ} \mathrm{C}$;

d) $\alpha[1,10,10,1]=f(\tau)$ - average heat transfer coefficient between drops and ambient air in the cell $[10,10$, $1], \mathrm{W} /\left(\mathrm{m}^{2} \mathrm{~K}\right)$;

e) $w_{d}[1,10,10,1]=f(\tau)$ - average speed of drops in the cell $[10,10,1], \mathrm{m} / \mathrm{s}$.

\section{Results of simulation tests and their analysis}

This section presents the results and an analysis of simulation tests. Firstly, the analysis targets the impact of the average diameter of drops on the heat flux received and the average temperature in the chosen cell depending on the degree of droplet dispersion. Both studies are presented separately for two sprinkling intensities, namely, $5 \mathrm{~mm} / \mathrm{min}$ and $10 \mathrm{~mm} / \mathrm{min}$. The review also considers the average drop speed and the heat transfer coefficient at a sprinkling intensity of $5 \mathrm{~mm} / \mathrm{min}$. Finally, changes in temperature for all simulation tests including the case without extinguishing are presented and discussed. Besides, a comparative analysis focuses on characteristic values, such as the maximum temperature in the cell, time of its achievement, the maximum heat flux received and the maximum rate of temperature growth.

Figure 3 gives values of the heat flux received from the tested cell $Q_{g}$ during fire extinguishing using a mist jet for three different average drop diameters and sprinkling intensity equalling to $5 \mathrm{~mm} / \mathrm{min}$.

The rapid growth in the value of the received heat flux immediately after initiating the extinguishing process can be observed in all tested scenarios. In the case of drops with the average diameter of $0.3 \mathrm{~mm}$, a peak value of $79 \mathrm{~W}$ initially occurred, after which the value suddenly dropped to $39 \mathrm{~W}$ and then, a gradual growth to the maximum value of about $275 \mathrm{~W}$ was recorded. This happens because large amounts of energy are received by convection after activation of the mist nozzle, resulting from a significant difference in temperature between the heated air and water drops. For other diameters $(0.6 \mathrm{~mm}$ and $0.9 \mathrm{~mm}$ ), the increase was not as significant, and the heat flux reached lower values. The differences between maximum values of heat flux for analysed diameters of drops exceed $100 \mathrm{~W}$.

Figure 4 shows the same dependence, the only difference being that the average sprinkling intensity is now $10 \mathrm{~mm} / \mathrm{min}$. Differences recorded between courses for the same average droplet diameters are not as significant anymore as at the intensity of $5 \mathrm{~mm} / \mathrm{min}$. There is also a visible characteristic peak in values of heat flux received

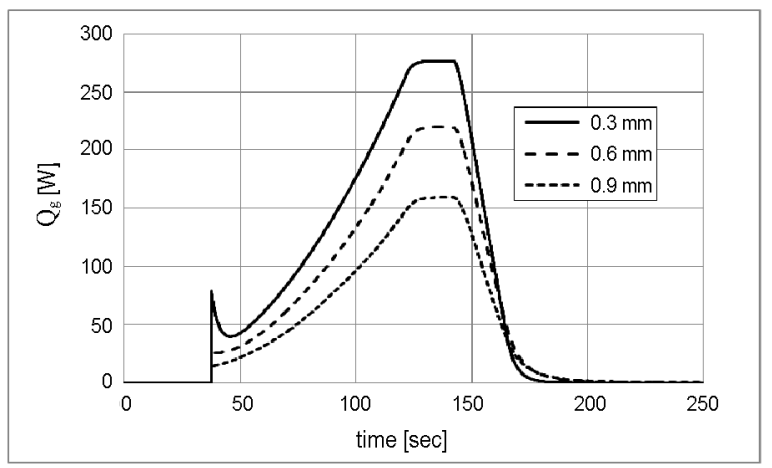

Fig. 3. Heat fluxes received from cell $[10,10,1]$ by sprayed fog stream for different average drop diameter at a sprinkling intensity of $5 \mathrm{~mm} / \mathrm{min}$ 


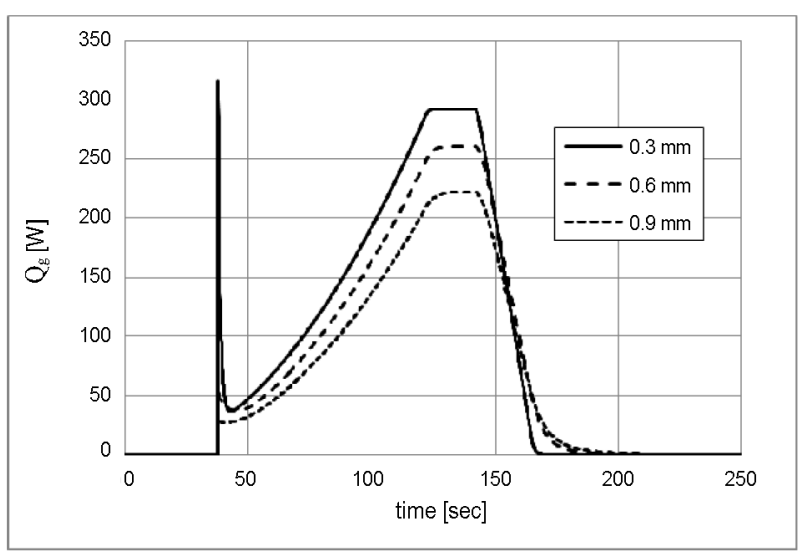

Fig. 4. Heat fluxes received from the cell $[10,10,1]$ by the sprayed fog stream for different average drop diameters at the sprinkling intensity of $10 \mathrm{~mm} / \mathrm{min}$

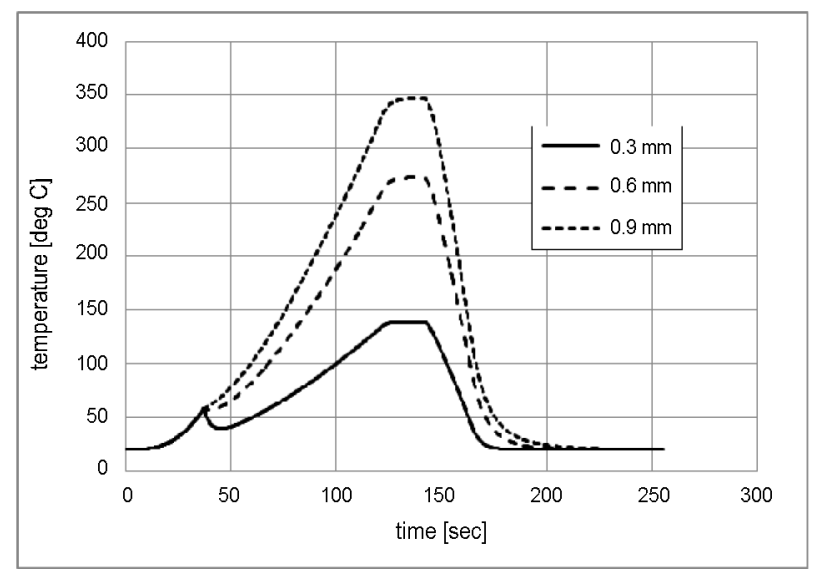

Fig. 5. Average temperature in the cell $[10,10,1]$ by the sprayed fog stream for different average drop diameters at the sprinkling intensity of $5 \mathrm{~mm} / \mathrm{min}$

at the time of activation for the average diameter of drops equalling to $0.3 \mathrm{~mm}$, which grows to $316 \mathrm{~W}$. Similarly as before, the value of the received heat flux increases with a decrease in the droplet diameter. The highest values were obtained for a droplet stream with an average diameter of $0.3 \mathrm{~mm}$, and the smallest results were generated by a fog with the average droplet diameter of $0.9 \mathrm{~mm}$. The increase in the sprinkling intensity affects the growth of the received heat flux. This is particularly visible at the time when extinguishing is activated and for the majority of droplet diameters. The course of $Q_{g}$ with the use of average droplet diameter of $0.6 \mathrm{~mm}$, at a higher average sprinkling intensity of $10 \mathrm{~mm} / \mathrm{min}$ shows that the amount of received heat is comparable to the one obtained at the average droplet diameter of $0.3 \mathrm{~mm}$ and the smaller sprinkling intensity of $0.5 \mathrm{~mm} / \mathrm{min}$.

The charts of the average temperature in a chosen cell of the room using a different average drop diameter are shown in Figure 5. The results were obtained for the average sprinkling intensity equal to $5 \mathrm{~mm} / \mathrm{min}$. The heat flux received by droplets with smaller diameters causes the analysed cell to have much lower temperatures. A de-

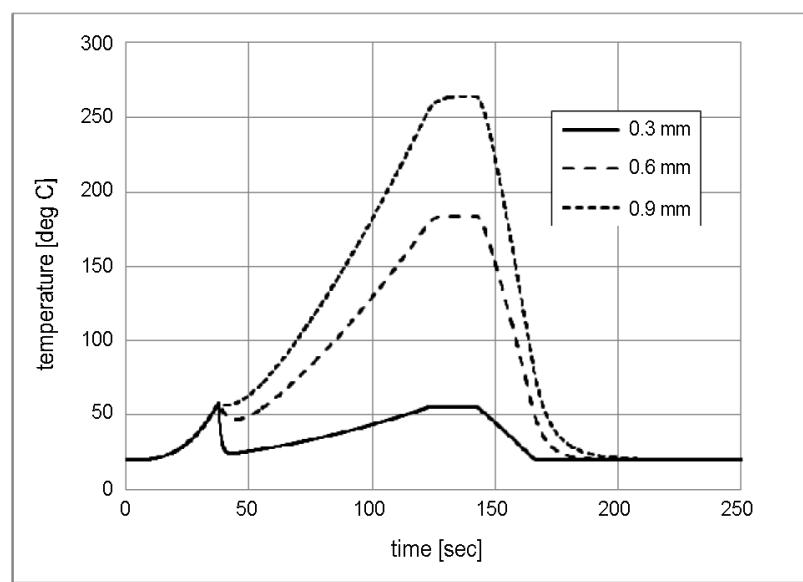

Fig. 6. Average temperature in the cell $[10,10,1]$ for different average drop diameters at the sprinkling intensity of $10 \mathrm{~mm} / \mathrm{min}$

cline of almost two times and one and a half times in temperature during extinguishing, using droplets of the average diameter of $0.3 \mathrm{~mm}$ as compared to droplets of the diameter of $0.9 \mathrm{~mm}$, confirms a much more effective use of cooling properties of finely sprayed water.

Figure 6 shows the course of temperature in the analysed cell for a two-fold larger average sprinkling intensity equalling to $10 \mathrm{~mm} / \mathrm{min}$. After the start of extinguishing, greater decreases in temperature than at lower sprinkling intensity were recorded. The biggest decline occurred at the largest degree of dispersion. For the average diameter of drops amounting to $0.3 \mathrm{~mm}$, the temperature dropped from $60{ }^{\circ} \mathrm{C}$ to $24{ }^{\circ} \mathrm{C}$. The fire was almost fully under control in the first seconds of extinguishing, and throughout the extinguishing process, the temperature did not exceed $60{ }^{\circ} \mathrm{C}$. This can be explained by a very large increase in heat flux received at the first time (Fig. 4). This value, which exceeded $300 \mathrm{~W}$, was sufficient to suppress the fire in its incipient stage only using the cooling properties of water. However, it should be noted that in the case of many combustible materials, even a lower efficiency of heat received by mist spray may be sufficient to interrupt the combustion process.

The simulation program also allowed obtaining a course of the average value of droplet speed in the extinguishing process. The velocity of droplets was subject to slight fluctuations that did not exceed $0.3 \mathrm{~m} / \mathrm{s}$. The most fragmented mist (the average diameter of $0.3 \mathrm{~mm}$ ) reached the smallest droplet speed below $3 \mathrm{~m} / \mathrm{s}$. In the case of the biggest droplet diameter amounting to $0.9 \mathrm{~mm}$, the maximum value of the average speed was up to $5 \mathrm{~m} / \mathrm{s}$.

The program also includes a simulation result without extinguishing. The analysis allows finding the diameters and sprinkling intensity that are the most efficient with respect to extinguishing effectiveness. A decline in the temperature by almost $200{ }^{\circ} \mathrm{C}$ was simultaneously recorded even in the case of the smallest extinguishing efficiency, which was obtained for sprinkling intensity of $5 \mathrm{~mm} / \mathrm{min}$ and the average drop diameter of $0.9 \mathrm{~mm}$. 
A comparison of temperature enables an estimation of the impact of each parameter on the extinguishing effectiveness. For this purpose, Table 2 lists the selected characteristic values for the heat flux $Q_{g}$ and temperature $t$, such as the maximum values and time of its achievement, as well as the maximum speed of growth. The differences between the maximum temperature obtained during two simulations $\left(I=5 \mathrm{~mm} / \mathrm{min}, \delta_{0}=0.9 \mathrm{~mm}\right.$ and $I=10 \mathrm{~mm} / \mathrm{min}, \delta_{0}=0.3 \mathrm{~mm}$ ) are almost six-fold, which substantiates the existence of a significant difference in the extinguishing effectiveness of those two fog streams. It should be noted that the sprinkling intensity also has a considerable impact on the general simulation result as the droplet diameter. The temperature growth rate of the heat flux received by the stream containing droplets of the diameter of $0.6 \mathrm{~mm}$ and the intensity of $5 \mathrm{~mm} / \mathrm{min}$ is comparable to the stream that contains droplets of the diameter of $0.9 \mathrm{~mm}$ but the intensity of $10 \mathrm{~mm} / \mathrm{min}$.

The time to reach the maximum temperature is the shortest for drops that have the average diameter of $0.3 \mathrm{~mm}$ and the sprinkling intensity of $10 \mathrm{~mm} / \mathrm{min}$. It supports the fact that following the activation of extinguishing (about 37 seconds after the ignition), the fire could not develop any further. In other cases, this time corresponds to the maximum value of $Q_{f}$ (the heat release rate) and is equal to about 132 seconds.

To make it easier to draw conclusions, the obtained results were summarised in Table 2 to present characteristic values of the heat $Q_{g}$ and temperature t, i.e. the maximum value of temperature $T_{\max }$, the time until its achievement, the maximum rate of temperature increase $d t / d \tau_{\max }$ and the maximum value of the stream $Q_{g \max }$. Those values refer to a single selected cell having the coordinates $[10,10,1]$.

The last item in the Table refers to the fire scenario, which did not take extinguishing into consideration.

Table 2. Characteristic values of the heat flux and temperature

\begin{tabular}{|c|c|c|c|c|c|c|}
\hline No. & $\begin{array}{l}I \mathrm{~mm} \\
\mathrm{~min}\end{array}$ & $\begin{array}{c}\delta_{0} \\
\mathrm{~mm}\end{array}$ & $\begin{array}{c}t_{\max } \\
{ }^{\circ} \mathrm{C}\end{array}$ & $\begin{array}{c}\text { Time to } \\
t_{\max } \\
\sec \end{array}$ & $\underset{\mathrm{W}}{Q_{\text {gmax }}}$ & $\begin{array}{c}d t / d \tau_{\max } \\
{ }^{\circ} \mathrm{C} / \mathrm{s}\end{array}$ \\
\hline 1. & & 0.3 & 38.67 & 135.95 & 776.55 & 0.90 \\
\hline 2. & & 0.6 & 273.10 & 136.70 & 220.29 & 1.98 \\
\hline 3. & & 0.9 & 346.72 & 141.50 & 158.98 & 2.59 \\
\hline 4. & \multirow{3}{*}{10} & 0.3 & 58.04 & 37.55 & 315.68 & 0.21 \\
\hline 5. & & 0.6 & 183.85 & 133.60 & 261.04 & 1.26 \\
\hline 6. & & 0.9 & 263.86 & 138.65 & 222.37 & 1.91 \\
\hline 7. & - & - & 542.49 & 132.20 & 0.00 & 4.10 \\
\hline
\end{tabular}

\section{Conclusions and final remarks}

The objective of the study was to investigate the impact of the average sprinkling intensity and droplet diameter on the extinguishing effectiveness using computer simulation methods. For this purpose, a special program written by the first author was applied for modelling the extinguishing process using the spray generated by mist nozzles. The model was verified physically, mathemati- cally and by computing. The proof is in the results that indicate the correct trends in temperature changes in the room during a fire. The authors of this article plan to validate the model over the next few months and then describe the results in the following article.

On the basis of the obtained results and their analysis presented in Section 3, the following conclusions were formulated:

1. A larger the degree of atomization characterized by a smaller average droplet diameter is conducive to achieving the extinguishing effectiveness of the fire. At its three-fold reduction (from $0.9 \mathrm{~mm}$ to $0.3 \mathrm{~mm}$ ), almost a two-fold increase was achieved in the maximum heat flux values received (from about $158 \mathrm{~W}$ to $277 \mathrm{~W}$ ) for the sprinkling intensity of $5 \mathrm{~mm} / \mathrm{min}$. In turn, for a two-fold increase in the sprinkling intensity (from $5 \mathrm{~mm} / \mathrm{min}$ to $10 \mathrm{~mm} / \mathrm{min}$ ), this increase was slightly smaller (by ca. one and a half times, from approx. $222 \mathrm{~W}$ to $316 \mathrm{~W}$ ). These results suggest significant advantages of mist systems over conventional sprinklers, where the average droplet diameter is substantially larger. The increase in fragmentation of the water increases the efficiency of its cooling properties, which significantly reduces the need for water.

2. The average droplet diameter has a significant impact on the maximum temperature and the average speed of its growth. A three-fold reduction in the droplet diameter causes a reduction in the maximum temperature, which is more than a double (from $347^{\circ} \mathrm{C}$ to $139^{\circ} \mathrm{C}$ ), provided the average sprinkling intensity is $5 \mathrm{~mm} / \mathrm{min}$; and almost a five-fold reduction (from $264{ }^{\circ} \mathrm{C}$ to $58{ }^{\circ} \mathrm{C}$ ) is achieved at the average sprinkling intensity of $10 \mathrm{~mm} / \mathrm{min}$. The reduction in the droplet diameter causes a significant decrease in the temperature growth (from $2.59{ }^{\circ} \mathrm{C} / \mathrm{s}$ to $0.90{ }^{\circ} \mathrm{C} / \mathrm{s}$ at $I=5 \mathrm{~mm} / \mathrm{min}$ and from $1.91{ }^{\circ} \mathrm{C} / \mathrm{sec}$. to $0.21{ }^{\circ} \mathrm{C} / \mathrm{sec}$. at $I=10 \mathrm{~mm} / \mathrm{min}$ ). At a lower sprinkling intensity $I=5 \mathrm{~mm} / \mathrm{min}$, the insignificant impact of the average drop diameter on time to achieve the maximum temperature was recorded (the time is shorter by only ca. 5 seconds at the three-fold reduction in the drop diameter). On the other hand, the situation was completely different for a higher value of the sprinkling intensity. In such a case, if the droplet diameter is changed from $0.6 \mathrm{~mm}$ to $0.3 \mathrm{~mm}$, the time is shorter by more than three times (from about 134 seconds to about 38 seconds).

3 . The sprinkling intensity affects both the maximum temperature and the speed of its growth as well as the received heat flux. The lower is the average diameter of a droplet, the higher is the sprinkling intensity. For $\delta_{0}=0.3 \mathrm{~mm}$, a double increase in the sprinkling intensity causes a decrease of about two and a half times in the maximum temperature (from $139{ }^{\circ} \mathrm{C}$ to $58^{\circ} \mathrm{C}$ ) and an almost four-fold decrease of its growth rate (from $0.90{ }^{\circ} \mathrm{C} / \mathrm{sec}$ to about 
$\left.0.21^{\circ} \mathrm{C} / \mathrm{sec}\right)$. At the same time, an increase was recorded in the maximum value of the heat flux received from a single cell, but only by about $14 \%$ (from $280 \mathrm{~W}$ to $316 \mathrm{~W}$ ). For $\delta_{0}=0.9 \mathrm{~mm}$, this increase was larger and equalled to approx. $40 \%$, but was not transposed into a corresponding reduction in the value of the maximum temperature (from $347^{\circ} \mathrm{C}$ to $255^{\circ} \mathrm{C}$ or about $31 \%$ ) and its growth rate (from $2.59{ }^{\circ} \mathrm{C} / \mathrm{sec}$. to $1.91{ }^{\circ} \mathrm{C} / \mathrm{sec}$. or about $36 \%$ ).

4. A comparison of maximum values of temperature and the speed of its growth during a fire without and with extinguishing allows ascertaining that even in the worst-case scenario, with the use of water spray consisting of droplets of the largest average diameter and the lowest sprinkling intensity, they were significantly reduced (from $540{ }^{\circ} \mathrm{C}$ to $345^{\circ} \mathrm{C}$ and from $4.10^{\circ} \mathrm{C} / \mathrm{sec}$ to $\left.2.59{ }^{\circ} \mathrm{C} / \mathrm{sec}\right)$. In the case of the best extinguishing option, i.e. the spray consisting of the smallest diameter droplets and a greater sprinkling intensity, differences between the maximum temperature and the growth rate were significantly noticeable: the decrease in temperature was almost ten-fold (from $540{ }^{\circ} \mathrm{C}$ to $58^{\circ} \mathrm{C}$ ), and the average growth rate was almost twenty times lower (from $4.1{ }^{\circ} \mathrm{C} / \mathrm{sec}$ to $0.21^{\circ} \mathrm{C} / \mathrm{sec}$ ).

The summary of the obtained results indicates that mist jets characterized by a high degree of dispersion and a high sprinkling intensity provide the greatest effectiveness in the extinguishing process. The best results for the tested scenarios were obtained for the spray with the average droplet diameter equal to $0.3 \mathrm{~mm}$ and the sprinkling intensity of $10 \mathrm{~mm} / \mathrm{min}$. The cooling properties of water mist become enhanced at the time of activation of the extinguishing and achieving the maximum power of fire, which proves the usefulness of water mist in extinguishing high power fires.

When analysing the possibility to use higher sprinkling intensities, it should be taken into account that the water consumption coefficient remains constant when increased. Consequently, it would be advisable to consider whether a better solution would be to assume an even finer water atomization so that it could receive more heat under a smaller water usage. It would also be necessary to verify the way, in which a further decrease in the droplet diameter would affect the extinguishing properties of water fog. The use of smaller droplets may be right for specific groups of fires because in some cases, a higher intensity of spraying may be needed to extinguish a fire. It should also be considered whether an increase in the sprinkling intensity above a certain threshold would not cause condensation of water mist. This could have adverse effects in many applications, for example when extinguishing electronic devices on fire.

In the future, the program could become an important tool for simulation of water mist extinguishing system, which is becoming more frequently used for fire protection.
In computer simulations of the extinguishing process, estimation of the amount and rate of received heat must leave some margin of error due to the complex nature of the fire phenomenon. To verify the results obtained by the simulation, they should be compared with parameters and values obtained during tests carried out under real conditions. The model used in the program is still under development, and results can be used for a more accurate description of some processes to present the actual course of a fire as closely as possible.

The development of the model could take into consideration the function of applying water mist streams during extinguishing activities. Numerous studies have been conducted with respect to extinguishing systems while little attention was paid to the effects of these actions. For example, the use of a water spray should consider a number of adverse effects. Air contracting of air during a water flow may result in increased combustion intensity during the initial application of water mist. Another hazardous phenomenon, which occurs during the use of a water spray, is the piston effect, which causes pushing of fire and smoke into places that were not caught on fire. The computer model could solve the problem of hazards associated with the use of water mist for extinguishing an internal fire and help develop appropriate tactics and strategies to fight a fire and effectively exploit its potential without exposing the rescuers to potential dangers.

Work on the extinguishing model is continued to allow its further development, for example by taking into account the unevenness of sprinkling, the complex process of droplet decay and the reduction in their diameter as a result of evaporation.

\section{References}

Cong, B. H.; Liao, G. X. 2005. Review of modeling fire suppression by water sprays by computational fluid dynamics, International Journal on Engineering Performance-Based Fire Codes 7(2): 35-56.

Davis, S. K. 2000. Fire fighting water: a review of firefighting water requirements. Fire engineering research report $2000 / 03$. University of Canterbury, Christchurch, New Zealand.

Gałaj, J. 2009. A general concept of fire hybrid modelling in compartments, Journal of Civil Engineering and Management 15(3): 237-245. http://dx.doi.org/10.3846/1392-3730.2009.15.237-245

Gałaj, J. 2010a. A new version of hybrid model of fire in compartments, in Proceedings of the $10^{\text {th }}$ International Conference "Modern Building Materials, Structures and Techniques", 2010, Vilnius, Lithuania, 1203-1209.

Gałaj, J. 2010b. A hybrid approach to modelling of fire in compartments, in Proceedings of International Conference on Modelling and Simulation ASME, 21-26 June 2010, Prague, Czech Republic.

Gałaj, J.; Konecki, M. 2010. Modification and validation of chosen fire zone models, in Proceedings of International Conference on Modelling and Simulation ASME, 21-26 June 2010, Prague, Czech Republic. 
Gałaj, J.; Półka, M.; Sukys, R. 2013. Influence of the addition of fire retardants on fire properties of materials based on polyester resin Polimal 1033 APy, Journal of Civil Engineering and Management 19(3): 456-464. http://dx.doi.org/10.3846/13923730.2013.788549

Grant, G.; Breton, J.; Drysdale, D. 2000. Fire suppression by water sprays, Progress in Energy and Combustion Science 26(2): 79-130. http://dx.doi.org/10.1016/S0360-1285(99)00012-X

Grimwood, P. 2002. Flashover and nozzle techniques. Crisis and Emergency Management Centre (CEMAC). 202 p.

Grimwood, P.; Desmet, K. 2003. Tactical firefighting. A comprehensive guide to compartment firefighting and fire training version 1.1. Crisis and Emergency Management Centre (CEMAC).

Hanuska, C. P.; Black, G. G. 1993. Engineering criteria for water mist fire protection systems. An overview of water mist fire suppression systems technology. Hughes Associates, Columbia.

Jones, W. W.; Peacock, R. D.; Forney, G. P.; Reneke, P. A. 2009. CFAST - consolidated model of fire growth and smoke transport. Technical Reference Guide (version 6). NIST Special Publication, No 1026.

Konecki, M.; Półka, M. 2009. Simple fire model for comparative studies of critical conditions during combustion of chosen polymer materials, Journal of Civil Engineering and Management 15(3): 247-257. http://dx.doi.org/10.3846/1392-3730.2009.15.247-257

Mawhinney, J. 2012. Issues and future directions for water mist fire protection systems, Fire Protection Engineering, 2nd quarter, 2012.

Mawhinney, J.; Solomon, R. 2000. Water mist fire suppression systems NFPA, in A. E. Cote, J. L. Linville. Fire protection handbook. $18^{\text {th }}$ ed. NFPA.
McGrattan, K.; Hostikka, S.; Floyd, J.; Baum, H.; Rehm, R. 2007. Fire dynamics simulator. Technical reference guide (version 5). NIST Special Publication.

Myree, S. 2008. Fire suppression and water mist systems, Library \& Archival Security 21(2): 169-176. http://dx.doi.org/10.1080/01960070802201920

National Fire Protection Association (NFPA). 2000. NFPA 750 standard on water mist fire protection systems.

National Fire Protection Association [online]. 2015 [cited 26 January 2015]. Available from Internet: fire.nist.gov/bfrlpubs/fire04/PDF/f04060.pdf

Novozhilov, V. 2001. Computational fluid dynamics modeling of compartment fires, Progress in Energy and Combustion Science 27: 611-666. http://dx.doi.org/10.1016/S0360-1285(01)00005-3

Orzechowski, Z.; Prywer, J. 2008. Wytwarzanie i zastosowanie rozpylonej cieczy. WNT Warszawa.

Palau, A. 2005. Through the mist, Fire Safety Engineering 7: $31-33$.

Półka, M.; Gałaj, J. M.; Karpovic, Z. 2013. Investigation of the influence of flame retardant additives on some fire properties of polyester materials applying small-scale testing technique, Journal of Civil Engineering and Management 19(4): 561-572. http://dx.doi.org/10.3846/13923730.2013.793610

Telesto Sp. z o. o. [online]. 2015 [cited 17 January 2015]. Available from Internet: www.telesto.pl/informacje/technologia

Whiteley, B. 2009. Water mist - standards and applications, Fire Safety Engineering 16: 21-22.

Zbrożek, P.; Prasuła, J. 2009. Wpływ wielkości średnic kropli mgły wodnej na efektywność tłumienia pożaru i chłodzenie, Bezpieczeństwo i Technika Pożarnicza. 3. 20

Jerzy GAŁAJ. Assoc. Prof. PhD, Head of Hydromechanics Division at the Department of Fire Safety Engineering, the Main School of Fire Service, Warsaw. Publications: author of over 100 scientific publications. Research interests: fire modelling, modelling of extinguishing systems, fire safety engineering, full-scale fire tests, flow characteristics of firefighting systems.

Marek KONECKI. Assoc. Prof. PhD, Head of the Fundamentals of Combustion, Explosion and Extinguishing Division at the Department of Fire Safety Engineering, the Main School of Fire Service, Warsaw. Publications: author of over 70 scientific publications. Research interests: fire development, fire modelling, fire safety engineering, small and full-scale fire tests, smoke generation.

Ritoldas ŠUKYS. Assoc. Prof. PhD, Head of the Department of Labour Safety and Fire Protection, Vilnius Gediminas Technical University (VGTU). Publications: author of over 36 scientific publications. Research interests: human safety, safety engineering. 